\title{
早川家住宅における建築関係史料と濃尾地震後の耐震対策について
} - 近代和風建築早川家住宅に関する研究 その 1 -

\section{A STUDY ON HISTORICAL MATERIALS OF ARCHITECTURE AND SEISMIC COUNTERMEASURES ADOPTED AFTER THE NOBI EARTHQUAKE OF HAYAKAWA RESIDENCE}

- A study on the modern Japanese-style architecture, Hayakawa residence. Part. 1 -

$$
\text { 麓 和 善*1, 水野貴子*2, 濱田晋一*3 }
$$

Kazuyoshi FUMOTO, Takako MIZUNO and Shinichi HAMADA

\begin{abstract}
Hayakawa residence is a rural mansion that's preeminent modern Japanese-style house in Gifu prefecture that was severely damaged by the Nobi Earthquake in 1981. It can be confirmed from the historical materials and the remaining buildings, that during reconstruction, the head of the family, Shuzo Hayakawa, which had deep insight and intuition for architecture, was the one who decided planning and designing. Furthermore, it's clear that the adopted construction method of foundation and wooden frame took quake-resistance into account. Hayakawa residence is a pioneering example of wood frame construction modernizing, which takes quake-resistance into account.
\end{abstract}

Keywords : Modern Japanese-style houses, Shuzo Hayakawa, Historical material, Nobi Earthquake,

Seismic countermeasure

近代和風住宅，早川周造，文献史料，濃尾地震，而震対策，

\section{1. はじめに}

早川家住宅は, 岐阜県屈指の近代和風住宅であり, 農村邸宅であ る[写真 1 ]。筆者は, 岐阜県近代和風建築総合調査にかかわったが, 田園地帯にある地主層の大邸宅を, 当時の一般的な農家と区別して, 農村邸宅と称することにした 1)。一般的には，民家を農家と町家に 分類しているが，近代以降の優れた意匠性を備えた大邸宅を，農家 とは同一視できなかったためである。早川家に限らず，同様の大邸 宅の当主の多くは, 実業家や大商人との交流もあり, 高い教養を備 えた文化人で, 近代数寄者でもあった。そして, 未だ建築家として の職能が確立する以前は, 大邸宅の建設に際して，大工よりも，む しろ建築に造詣の深い当主の意向によって, 平面計画, 意匠計画が 行われたと考えている。良い意味での普請道楽である。早川家には， 住宅建設に際して，そのような当主の関わり方を具体的に知ること ができる文献史料が豊富に残されている。加えて, 早川家は, 明治 24 年（1891）の濃尾地震で甚大な被害を受け, 主屋他の主要な建物 が震災直後に再建された。再建に際しては, 先駆的耐震対策が講じ られ，近代初期における耐震対策を，具体的に知ることができる。
早川家住宅に関する既往研究としては，中村昌生による『和風建 築』の連載論文がある(以下中村論文と略す $)^{2)}$ 。その中で，文献史料 をもとに, 濃尾地震の被害と再建にかかわる早川家主屋の耐震対策, 平面計画の変遷や，茶匠等とのかかわりの中で決定された意匠的特 徵が，詳細に述べられている。また，耐震対策については，清水隆 宏・河田克博による概要の報告もある 3)。しかしながら，当時用い られた文献史料のほかにも, 多くの未整理史料があり, 最近になっ てそれらの史料の整理が終わった。そして，これらの史料を悉皆的

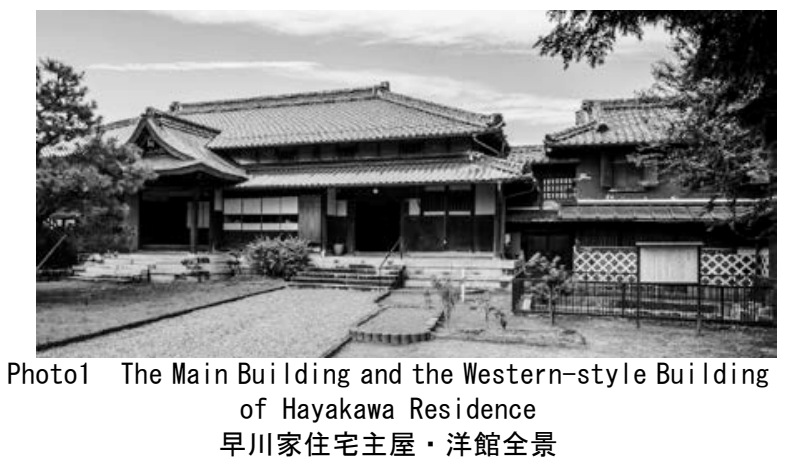

*1 名古屋工業大学大学院社会工学専攻 教授・工博

*2 名古屋工業大学大学院社会工学専攻 博士後期課程

*3 (公財) 文化財建造物保存技術協会 博士 (工学)
Prof. Dept of Architecture, Graduate School of Socio Engineering. Nagoya Institute of Technology, Dr.Eng.

Grad. Student, Graduate School of Socio Engineering, Nagoya Institute of Technology

The Japanese Association for Conservation of Architectural Monuments, Dr.Eng. 
に分析することによって,多くの新知見を得ることが可能になった。 本研究は, 早川家住宅に関寸る文献史料の悉皆的調查と, 現存建物 の現地調查をもとに, 早川家住宅の近代和風建築としての特質を明 らかにすることを目的とする。本稿は，その第 1 報として，早川家 所蔵史料の中から建築関係史料の全容を紹介寸るとともに, 特に重 要な史料 1 『記録帳』他を用いて, 濃尾地震の被害と再建における 耐震対策について, 詳しく考察するものである。

\section{2. 早川家住宅の概要}

早川家住宅は海津市平田町に所在し,多くの参詣人でにぎわう〈お 千代保稲荷〉の参道の西側に建つ。平田町は, 東西を木曽三川の長 良川・揖斐川に挟まれた三角州の中にあり, 周囲を堤防で囲んだ輪 中地域である。

明治 24 年濃尾地震当時の当主, 十七代早川周蔵は, 明治 16 年 10 月 に，父である理右衛門忠之が死去したため，若くして家を継いだ。 地元海津が度重なる洪水で疲弊しているのを憂慮し, 木曾三川治水 のために尽力した ${ }^{4)}$ 。また, 明治30年6月10日には, 多額納税者の互 選により, 貴族院議員に当選した。一方, 漸庵, 利徳庵と号し, 茶 人との交流も深く, 明治37年には, 名古屋春日町に煎茶趣味の別荘 「碧墅」も造営している。

\section{3. 文献史料}

早川家には膨大な文献史料が所蔵されているが，その中から建築 関係史料をまとめると，〔表 1〕のとおりとなる。史料 1『記録帳』 は, 明治 25 年 12 月から明治 43 年 5 月にかけて, 濃尾地震後の被害 と, 再建に関する諸記録, 再建後の水害等天災, および当家にかか わる重要事項を詳細に書き留めたものである。史料 2 から 18 は, 震 災後の復興に関する建設関係者, 材料明細, 各工事の経費等に関す る文書および扁額である。史料 19 から 32 は, 早川周造と茶匠（官 休庵宗守一指斎, 村瀬玄中, 磯谷宗庸) 他との間で交わされた書簡 である。これらの書簡から, 茶匠の指導・助言をもとに, 主屋や離 れの細部意匠を検討した過程を読み取ることができる。史料 33 から 84 は, 屋敷全体, 主屋, 離れ, 土蔵他に関する図面である。このう ち, 史料 $41 \cdot 46 \cdot 69$ は, 中村論文に掲載されているが, 現在は所在 が確認できない。史料 85 は主屋建設中の写真である。以上の文献史 料から, 早川家における震災後の建物の建設経緯を詳細に読み取る ことができる。

\section{4. 濃尾地震の被害}

史料1『記録帳』は，中村論文においてもその大半が引用されてい るが, 本稿においても考察の中心となる重要な文献であるので, 関 係する部分を原文に忠実に記しておく。

まず，冒頭において，次のとおり，濃尾地震を契機に，この記録 帳が作成されたことが記されている。

「（表紙） 紀元二千五百五十二年 記録帳

明治廿五年壬辰十二月

(本文)

記録)必要ナル今更喋々/(/印改行, 句読点筆者, 以下同) スルヨ俟タズ。然ルニ予家/古書類多シト虫(雖) トモ,一
定/継続シタル記録ナシ。故ニ/明治廿四年十月廿八日ノ/ 大震災ヨ一紀元トシ, 一/家ノ重大ナル事件 7 , 此/帳簿二 記述スル事トス。

明治廿五年十二月/十七代/早川周造/謹識」

次に濃尾地震の惨状が記され，早川家住宅における震災時の建 物について, 被害状況に応じて, 大きく「全倒ノ部」,「半倒ノ部」,

「無害之部」に分類したうえで，各建物の由来と被害状況が，簡潔 に記されている。

「維時明治廿四年十月廿八日午/前七時, 轟然ノ一声卜共二, 前/ 古未聞ノ激震 7 生シ, 地裂, 水/湧, 沙出, 僅カ二五六分ノ間二, 幾/万ノ人畜, 幾千ノ家屋 7 殺/傷シ, 倒壊シ, 其惨害濃, 飛, / 尾，三，勢，江，越，信ノ各国二及/ビ，震動八五畿，東山，東 海, / 北陸, 山陰, 山陽/諸道二及ベ/リト云フ。此日, 余力家 宅ノ/倒壊セシモノ挙クル, 左ノ如シ。

全倒ノ部

一 書院 旧本宅西ノ方

明治十一戌寅十一月九日，十六代父理右衛門ノ建/設セラ レ, 棟梁名古屋三棟梁ノ一, 吉右衛門/ノ手二成ル。外観 華美ヨ主トシ, 地盤卜切組/二注意ナキ為メ, 新築二抱 (拘) ラス, 第一二/倒壊セリ。後世注意スベシ。

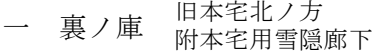
建設年度不詳, 曽祖父ノ代ナラン。此/庫之中, 道具习蔵セ リ。破壊頗ル多/シ。

一 油庫 旧本宅東ノ方 建設年度不詳。古朽修繥セント/シ, 計画中。

一 井戸屋形 旧本宅東ノ方 予カ廿二年建設セシモ/。四本柱ニシテ/壁ナクスシカイ梁 ナキノ故ナラン

一 味噌庫 油庫南ノ方 建設年度不詳。

一 長屋門 本宅ヨリ辰ノ方長拾間 建設年度不詳。朽廃セリ。/此長屋門ノ趾二, 仮宅ヨ設ケタ リ。

一 大工部屋 飯米庫卜辰巳庫, 予カ廿三年度ニ新設セシモノ。

一味噌庫中庫卜飯米庫, 建設年度不詳。

一 井戸屋形 本宅辰ノ方, 味噌庫 廃シテ一時水仕セザルモノ。新設年度/不詳。

外, 西ノ庫ヨリ裏門二至儿高塀全倒 。 半倒ノ部

一 本宅

建設年度未詳。唯曾祖父ノ頃/葍莫ヨ建上ケ瓦莫トセシ口/ 傳アリ。何レ百年余ノモノナラン。/右八老朽スルト共ニ, 修繥費ニ/多額ヨ要スル見込アルガ為メ, 他/エ売却スル事 トシ, 廿五年四月/取毁チ, 今安八郡西島村佐藤/丑松方二 建築アルモノ，乃チ旧本/宅ナリ。

一 裏ノ座敷 旧本宅ノ北ノ方 祖父ノ建設セシモノ。裏ノ庫ヨリ東エ/庇出シ作リタルモノ ナルニ, 裏ノ庫倒壊/シテ此座敷ノ倒壊セサルハ不思議/ナ 
Table1 List of Historical Materials on the Architecture of Hayakawa Residence 早川家建築関係史料

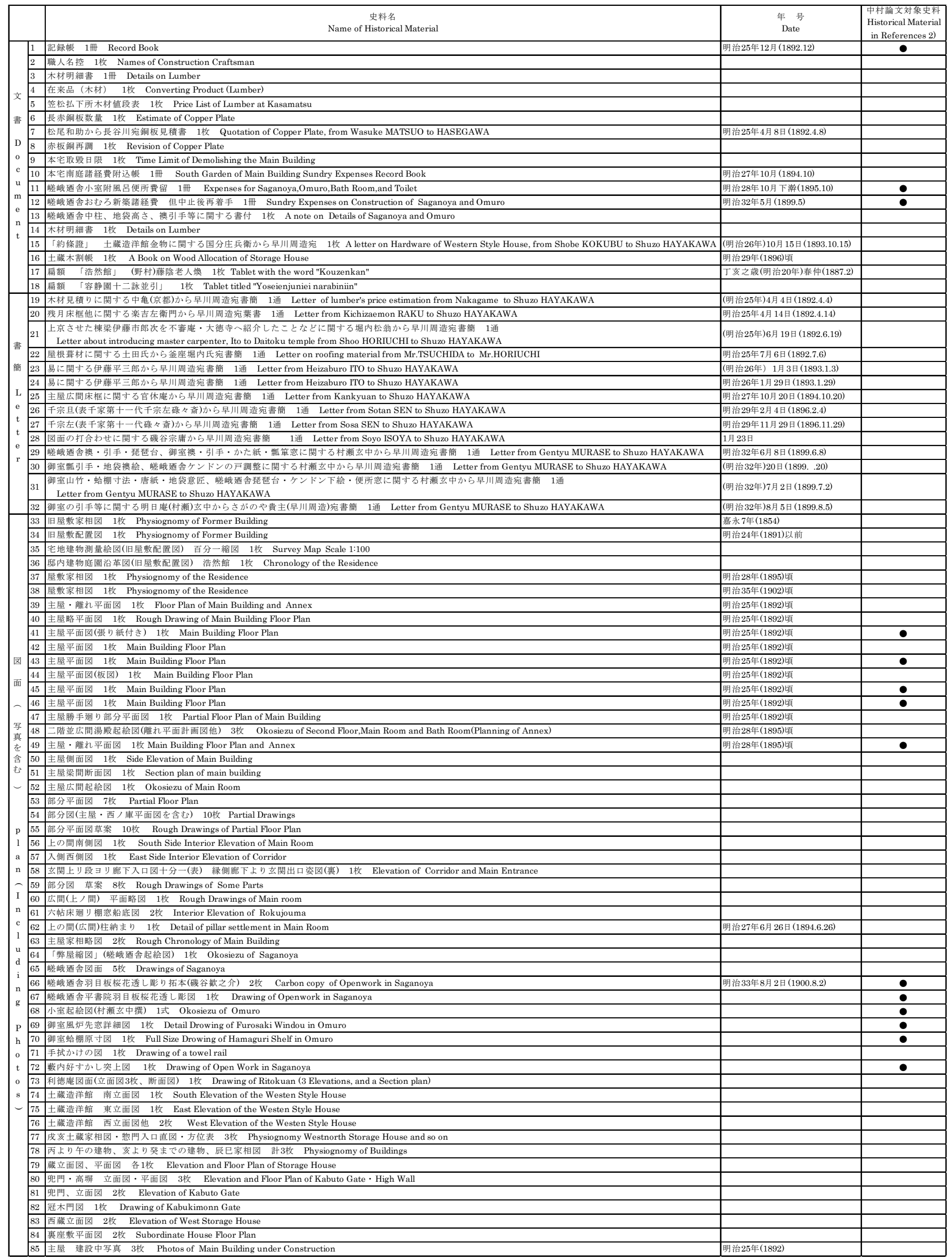


リ。廿五年七月, 本宅地ノ高上ケ/ト全時ニ, 修繥ヨ加へ,

セリ上ケ, 嵩上ケナシ。/下二炭入所 7 設ケ, 今二存置ス。

一 唇巳庫旧本宅辰巳

建設年度未詳。/此土蔵ヨ門ヨリ北ノ方ニ移シタリ。洋館卜 ノ間ノ塀/モ同時二出来セリ。大工治郎吉。明治廿九年十 二月一日移初么。

一 飯米庫 旧本宅南ノ方

一 利徳庵 旧本宅未申ノ方

附勝手 是八予力廿五年度, 利徳

祖父。父卜共謀シテ建設セシモ)。野寺村田中/宗匠ノ好 ( 京都堀内隺(鶴) 舅/四天王鳥飼事)。元部屋二/附属シタル モノ。又隠ヨ倣フテ建設シタルモノ。/万延元年庚申四月建 設。/明治廿八年, 大井二修繥 7 加へ, 庭前中門内庭, 碌々 斎好。

一 西ノ庫 旧本宅戌亥ノ方

父理右工衛門建築ニ係ル。道具蔵ナリ。/石垣ノ堅牢ニヨ

リ，倒壊ヨ免ル。

此土蔵明治廿九年, 両度ノ水害ニテ床上ニ達セリ。依テ大 修繕ヨ加へ仕リ。/新築ノ如クナリ。/地盤モ従来ヨリ二尺 二寸五分高义, 土台モ栗/六寸角トシ, 猶堅牢ニセリ。明治 廿九年十月五日，柱立 $/$ ナス。

一 廊下今日間

父理右衛門ノ建設ニ係ル。

無害之部

一 今日庵 此庭全体吉田紹和

附 梅見門

腰 掛 父理右衛門建設

餝雪隠 全上

予力十九年度十二月, 千宗室ノ方ニ/アル, 乃チ裏千家有名ノ

本形ヨ模シタル/モ)。起絵図吉田紹和, 大工名古屋数寄/屋

得意鎌蔵ノ建築ナリ。渾テ屋/根ノコケラニテ軽キニヨル。

一 裏門

予力建設セシモノ。大工村方森藤八。／切組/堅牢卜地盤 ノ注意ニヨル。

一 高塀 裏門ヨリ利徳庵

明治廿四年ノ建設。石垣ノ堅牢ニヨル。」

以上の被害状況と早川周造が考えた理由のうち, 耐震的観点から 特に注目される点をあげると，次のとおりとなる。

(1) 書院は, 明治 11 年建設で, 建設後 10 年余りながら, 意匠を重視 し，地盤と構造に注意を払わず建設したため，全倒した。

(2) 明治22年に建設された井戸屋形は, 壁が少なく, 筋違梁 (火打 梁)がなかったため倒壞した。

(3) 一方, 半倒の西ノ庫は, 石垣が堅牢であったため倒壊を免れた。

(4) 屋根が柿莫で軽い今日庵と, 構造を堅牢にし, 地盤に注意を払 った裏門，石垣が堅牢であった高塀は，被害がなかった。

\section{5. 濃尾地震後の復興}

濃尾地震の被害に続き, 『記録帳』には新築に関する次の記述が ある[写真 2]。

「新築セシモノ/附借家

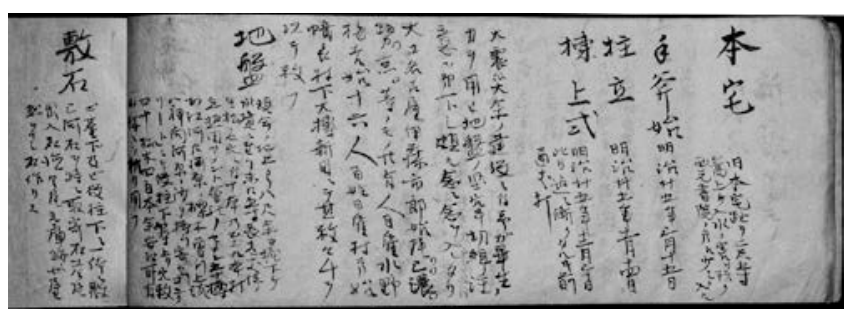

Photo2 Historical Material No. 1, "Record Book" 1892, Hayakawa Family Collection

\section{史料 1 『記録帳』明治 25 年 早川家所蔵}

(中略)

本宅旧本宅趾ヨ二尺五寸

嵩上ケ, 入水, 害习防ク

西之書院ノ方江少シク入ル

手斧始 明治廿五年三月十五日

柱立＼cjkstart明治廿五年十一月十四日

棟上式 明治十五年十二月三十日

此日迄ニ漸クタルキ前 通丈打

大震災余ノ建設ニ付，予ガ畢生ノ/カヨ用ヒ，地盤ノ堅牢，切組

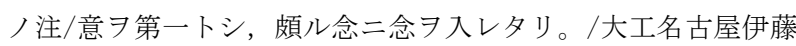
市郎始, 尾, 三，濃，/勢，京等ノモノ廿有人，日雇水野/梅吉 始十六人, 百姓日雇村方始/幡長村下大榑新田ニテ其数々千ヨ/ 以テ数つ。

地盤 現今ノ地上ヨリ八尺余习掘下ケ/水境二至リ。未口五寸, 長壱丈位ノ/生松, 壱穴二付, 十本乃至九本打/立, 熱田 セメント会社ノセメン五十樽, /安江河口河原ノ砅, 木曽 川上流/八神向河原ノ沙 $习$ 持于寄セ，「コンク/リート」 二テ役柱下築上リ, 穴数/四十, 松木四百本余, 安江所有 /山林ニテ伐リ用フ。

敷石 土台下及ビ役柱下二一体二敷, /三河石 特二取寄, 石工 今尾/出入石徳, 今尾元庫跡二小屋/懸ヨナシ, 石作リス。

木材 渾テ檜, ツカ類八, 妻里加茂郡/下麻生長谷川金左衛門, 名古屋/出張所ヨリ送ル。/大黒柱, 庭大黒, 入ロカブキ/ 鏡柱八，大坂浅田荷造方/ニテ上等ノ槻買入ル。/野物松 材八, 古来所有ノ幡長/松林, 居村松林二テ伐出ス。/丸 太類八，京都鷹ケ峯，杉柾タルキ，/小マイ，広小マイ 杉柾類八，京都高倉/押小路上ル中亀方ニテ買入，/奥拾 帖廻リ㴊，竿渕杉柾八，岐阜雛美 (見力) / 二テ買求，天井 板八, 元部屋ノ 7 用フ。/神棚ノ間天井板八, 元書院入側 ノ板。

一 千有余ノ上シ下シ壱丈ノ丸太, トマ八百牧, / 其他屋根 $コ$ 以 テ, 仮屋根Э懸ケ, 建前ス。

一 小屋組モ普通卜異リハサバ, 畑ニテ, 下ニテ一/度組, 其上 本建前又。

一 家相取調二付テハ, 高須小笠原臀生/担当シ, 名古屋水野南 北。東京ノ九星/堂。大垣ノ青木博皇堂。西京ニテモ堀/内 宗匠江倚頼シ，大家二人二相談ス。

一 座敷廻起絵図八, 吉田紹和ナリ。

一内法貫 7 柱二堀通ストキハ, 細キ柱ノ弱/ルヨ憂ヒ, 棟梁市 郎治ノ好ニテ鉄/丸 7 通シ, ボートーニテ攻メ込注意ス。 座敷, 裏座敷廻, 渾テニ用フ。 
一 雨戸八, 名古屋指物師芝川與八卜為, /受負出来ノ事。

一 地震梁卜云フ, 張天井ノ上ニ, 丸太 様注意セリ。

一 大戸類八渾テ, 名古屋古渡町/建具師山瀬鉄次郎 7 自宅 $/$ ヘ 呼寄セ, 切組サス。

一 庭迴建具, 奥座敷類/ノ障子類, 及玄関建具八, / 名古屋針 屋町堺町上ル/安田清七一統 八, 名古屋松川屋。

一 銅板八渾テ, 名古屋笹宗ニテ/買求, 莫方八, 京都筋川橋/ 梅吉一統莫立。

一 勝手障子類八, 今尾建具師/市野鍬之助ノ子, 及自村建具/ 治太郎致ス。

一 瓦八伊勢國東日野小 $\square$ 社外/二而特別二製造し, 莫方八/今 尾出入清八親子ナリ。

一 檜皮莫立関及雪隠廻リ莫方八, / 名古屋園井丁四番地田島国 太郎/仕事又。

一 赤樋八, 板八笹宗二テ買求, 細工八今/尾町須藤文治致ス。

一 壁下地八, 今尾日雇鎌吉一統。

一 壁今尾丁左官清吉一統。

一 瓦莫八, 今尾丁清八親子。

一 広間吉田紹和起絵図不完全/ノ処アリ。京都ヨリ武者小路小 川上ル/官休庵千宗守ヨ聘シ相談セリ。/故ニ床㴊ノ好アリ。 又ランマワク付ノ好/アリ。六畳席ニ和敬室ノ額アリ。/此 間多ク八楽吉左衛門之座敷 $7 /$ 模又, 其後名古屋村瀬玄仲来 リ，/種々相談ス。官休庵来臨ノ節，/手水鉢八枚 (鉢前) 組 ミ好么。

一 釘隠引手八, 浄益及名古屋/一東斎二申付出来セリ。釷類/ 八, 渾テ浄益。

一 欄間桐透官休好書附有。利/斎作リノ字ノ刻アリ。

一 襖シノブ。桐五(胡) 粉置。秋ノ野。/書院下二本引チリ金。 名古屋下/園町吉川弘道画。入側夜桜弦月/有。岐阜蒔 (牧) 田種麿。

一 本座敷, 次ノ間, 和敬室入側等ノ障/子類八, 名古屋袋町建 具職山田菊次/郎致又。尤壱人仕事。 (中略)

一 北ノ方二階付建物

明治廿六年癸巳八月廿日建前。/本宅棟梁伊藤市郎治一統/ ノ土 使フ

二階八小座敷及押入。/下八化粧ノ間及押入，庫工通フ/廊 下ニ用フ。

添物今日庵勝手廊下 $\square$ 用建/物, 明治廿七年六月廿日建前。

一 井戸屋形 東ノ方

明治廿六年九月七日建前。/大工伊藤市郎治一統习使フ。

一 唇巳 東方蔵造 上洋館, 清物

明治廿七年一月十七日建前。/大工伊藤市郎治一統。

一 艮ノ方

明治廿七年四月十二日ヨリ石垣着手。/巽卜甲ノ方八, 石垣 六月一日二着手。/六月十一日柱立。/大工市郎二一統, 石 工石徳組。
（中略）

庭

一 本宅前飛石, 中門前ヨリ西ノ方/大樫迄上リ段一面, 名古屋 市大須/村瀬玄仲好。

一 本宅手水鉢, 官休庵宗守好。

一 井戸燈籠位置，棕櫊楊橘植込，村瀬玄仲好。

一 利得庵前左右ツクバイ迄, 碌〉/斎好。

一 利得庵勝手前ツクバイノ下, 落/口辺, 自分好。

一 大石臥置，寒竹，松ノ位置，玄中/好。

一甲門 明治廿九年五月十二日

建前大工和七単独ニテ致ス。/甲門八, 裏千家表門ノ本形 /模シタルモノ。附リ高塀八自分好。大/工和七。莫工图太 郎。

(中略)

崕峨廼舎小室 附湯殿雪隠

さかの舎八磯谷宗庸好。をむろ八村瀬玄中好。其他/湯殿雪 隠予ノ好。

明治世二年六月五日午前八時建前。大工/名古屋市横三蔵町河村 和七外七人, 日雇鎌吉。

（中略）

下男部屋 門脇

明治世五年壬寅七月二日柱建。大工/中島郡(尾張国) 山崎村字 下枇杷首橋/本亀三郎，或今尾町鎌吉，石工/今尾町石徳，瓦伊 勢日野清左衛門，/大工助手村方秋次郎。

辰巳隅職人部屋

明治世五壬寅八月十三日柱建。大工/蛇池村惣十郎，日雇今尾鎌 吕，石工/今尾町石徳，瓦伊勢日野清左衛/門製。

表門 石柱地下へ五尺入込アリ

明治世五壬寅八月廿二日ヨリ着/手。全月廿九日石柱立。石工今 尾/石徳（後略）」

\section{5-1． 再建の経緯}

史料1『記録帳』によって明らかとなった再建の経緯を年表にまと めると，〔表2〕のとおりとなる。

加えて, 小屋裏の2枚の棟札〔写真3]にも次が記されている。 1 枚目裏 :「十七代/早川周造源精建之/明治二十五年辰十二月三十 日吉祥/名古屋住/番匠伊藤市郎治」

2枚目表 : 大工川村和七以下 20 名, 石工伊藤徳彌, 左官森清吉, 木 挽下平忠助, 同芳太郎, 日雇水野梅吉以下 16 名, 出入日雇牧野平吉, 森要四郎。

明治 24 年 10 月 28 日の濃尾地震から，わずか5か月弱の明治 25 年 3 月 15日に手斧始を行い, 木材の加工に取り掛かった。同年4月には旧主 屋の取り壊しにかかり，7月に新主屋のための地盤のかさ上げを行っ ている。そして同年11月14日に立柱，12月30日に上棟式を行い，こ の日までに正面側のみ垂木を打ち付けている。主屋の竣工について は記されていないが，上の間(広間)床廻りの柱と床框，落とし掛け の納まりを描いた明治27年6月26日付の図面 (史料62)があるので, 明 治27年後半には主屋の木工事を終え，ほどなく竣工したと考えられ る。離れである崕峨廼屋と御室(おむろ)および湯殿・雪隠は, 遅れ て明治32年6月5日に建前が行われた。 
Table2 Chronology of Hayakawa Residence's Reconstruction 早川家住宅再建年表

\begin{tabular}{|c|c|c|}
\hline 年号 & ate & In \\
\hline 24 & 1891 & 10.28 濃尾地震 The Nobi Earthquake \\
\hline 25 & 1892 & 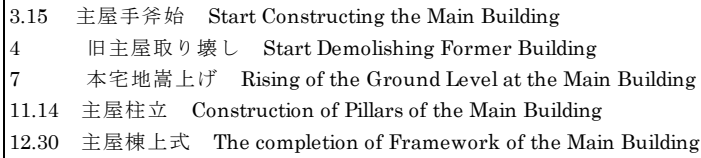 \\
\hline 26 & 1893 & $\begin{array}{l}8.20 \text { 北ノ方二階付建物建前 } \\
\text { Erection of Framework of the Two-storied Building at North Area } \\
9.7 \text { 井戸屋形建前 Erection of Framework of the Well Shed }\end{array}$ \\
\hline 27 & 1894 & $\begin{array}{l}\text { 1.17 土蔵造上洋館下米捣漬物ノ仕事場建前 } \\
\text { Erection of Framework of the Two-storied Storage House } \\
\text { 4.12 艮ノ方高塀石垣着手 Started the Construction of the Stone Wall } \\
\text { and the Fences at Northeast Area } \\
\text { 6.1日 盆栽室と甲ノ方高塀石坦着手 Started the Construction of the } \\
\text { Stone Wall and the Fences at the Bonsai-room and the Eastnorth Area } \\
\text { 6.11 同柱立 Construction of Pillars of Same Buildings } \\
\text { 6.20 今日庆勝手廊下口用建物建前 } \\
\text { Erection of Framework of the Building Attached to the Konnichian }\end{array}$ \\
\hline 28 & 1895 & 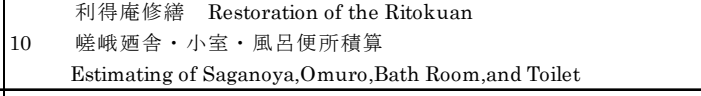 \\
\hline 29 & 1896 & 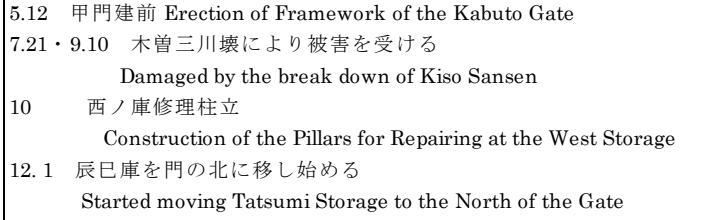 \\
\hline 30 & 1897 & 9.30 水害 A Flood Disaster \\
\hline 32 & 1899 & $\begin{array}{l}6.5 \text { 嵯峨廼舎 - 御室 - 湯殿雪隠建前 Erection of Framework of the } \\
\text { Saganoya,Omuro,Bath Room,and Toilet }\end{array}$ \\
\hline 35 & 1902 & $\begin{array}{l}\text { 7. } 2 \text { 下男部屋柱立 Construction of Pillars of the Servant Room } \\
8.13 \text { 唇巳隅職人部屋柱立 } \\
\text { Construction of Pillars of the Craftsman Room at the Eastsouth Area } \\
8.22 \text { 表門着手 Started the Construction of the Main Gate } \\
8.29 \text { 表門石柱立 Construction of Stone Pillars of the Main Gate }\end{array}$ \\
\hline
\end{tabular}

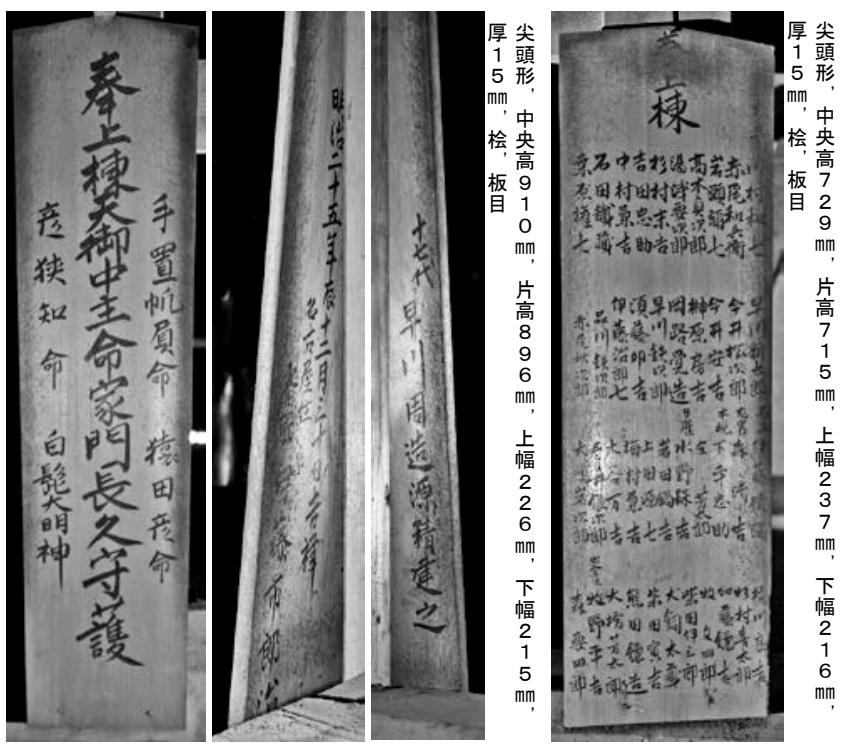

Photo3 Two Munafuda (wooden tags commemorating the foundation of the residence) December 30th, 1892 棟札 2 枚 明治 25 年 (1892) 12 月 30 日

\section{$5-2$. 建設関係者}

史料1『記録帳』および棟札の記述から, 主屋, 庭, 嵯峨廼舎, 御 室等の工事関係者の職種と人名をまとめると, 次のとおりとなる。

主屋
家相 高須 小笠原臀生, 名古屋 水野南北, 東京 九星堂,

大垣 青木博皇堂, 西京 大家二人

座敷廻起絵図 吉田紹和 (名古屋の茶匠)

ただし不備があり，京都の官休庵千宗守(茶匠)，名古屋の村瀬 玄仲(茶匠)に相談

雨戸 名古屋 指物師 芝川與八

大戸類 名古屋古渡町 建具師 山瀬鉄次郎

庭廻建具，奥座敷障子類，玄関建具

名古屋針屋町 安田清七一党 障子㴊塗 名古屋松川屋 銅板 名古屋 笹宗 莫方 京都筋川橋梅吉一党

勝手障子類 今尾 建具師 市野鍬之助の子

自村 建具屋治太郎

瓦 伊勢国東日野(清左衛門) 莫方 今尾町 清八親子 玄関・雪隠廻り 桧皮葺 名古屋園井町 田島国太郎

赤樋 板 笹宗 細工 今尾町 須藤文治

壁下地 今尾 日雇鎌吉一党 壁 今尾町 左官清吉一党 和敬室 - 入側等障子類 名古屋袋町 建具職 山田菊次郎 釘隠引手 中川浄益 (千家十職) 名古屋一東斎 釷類一切中川浄益

欄間桐透かし 官休庵 (茶匠) 好み

襖のシノブ・桐五 (胡) 粉置・秋ノ野・書院下二本引きチリ金 名古屋下園町 吉川弘道(絵師)

夜桜弦月 岐阜 牧田種麿(絵師)

本座敷，次の間，和敬室等障子類 名古屋袋町 建具職 山田菊次郎

庭

本宅前飛び石中門前より西の方大樫迄上り段一面

名古屋市大須 村瀬玄仲 (茶匠) 好

本宅手水鉢 官休庵宗守 (茶匠) 好

井戸燈籠位置棕櫚楊橘植込 村瀬玄仲 (茶匠) 好

利得庵前左右ツクバイ迄 碌〉斎 (茶匠) 好

利得庵勝手前ツクバイノ下落口辺, 自分 (早川周造)好

大石臥置, 寒竹, 松ノ位置 玄仲 (茶匠) 好

嵯峨廼舎御室附湯殿雪隠

さかの舎八磯矢宗庸 (茶匠) 好，をむろ八村瀬玄中 (茶匠) 好，

其他湯殿雪隠 予(早川周造) ノ好

大工 名古屋市横三蔵町 河村和七外七人

日雇鎌吉

まず，家相は高須の小笠原臀生が担当したが，合わせて名古屋， 東京, 大垣, 京都の家相師にも相談している。

意匠的に重要な, 座敷廻りや庭園については, 名古屋の茶匠吉田 紹和, 村瀬立仲, 磯矢宗庸, 京都の家元官休庵宗守, 碌〉斎がかか わっている。

各工事を担当したのは, 地元今尾の職人や, 名古屋の職人である が，釘隠と引手は千家十職として知られる中川浄益の作である。ま た襖絵等は, 名古屋の吉川弘道, 岐阜の牧田種麿の筆になる。

\section{$5-3$. 耐震対策 · 水害対策}

濃尾地震から得た教訓を生かし, 再建に際しては, 構造や耐震に 画期的な工夫が凝らされた。また輪中地域として, 水害対策も行わ 
れた。主な耐震対策，水害対策をまとめると，次のとおりとなる。

(1) 水害を防ぐため, 旧本宅の地盤より 2 尺 5 寸 $(758 \mathrm{~mm})$ かさ上げし

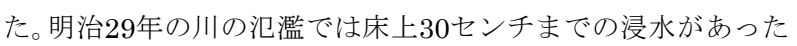
ことも『記録帳』に記されており, この地方では, いかに水害 に対する備えを入念に行わなければならないかがわかる。

(2) 地盤は, 現状を 8 尺 $(2424 \mathrm{~mm})$ ほど掘り下げると地下水位に達し た。そこに穴を 40 掘り，1 穴につき末口 5 寸 $(152 \mathrm{~mm})$, 長さ 1 丈 $(3030 \mathrm{~mm})$ 位の生松10本ないし9本を打ち立てた。地下水位より 下に松杭を打ったのは，腐朽のおそれがないためである。その 上にセメント 50 樽と安江河口河原の礫, 木曽川上流八神向河原 の砂を持ち寄せて作ったコンクリートを打ち, 役柱下を築き上 げた。ここにいう役柱とは一般的な部材名称ではないが，この 役柱下に基礎杭を打っており，その数が40か所と記されている。 試みに部屋隅の柱を数えると,40か所前後となる。したがって, 主屋全体が不同沈下しないように, 部屋隅など荷重を受ける場 所に用いた柱のことと考えられる。以上の基礎工事を，明治 25 年4月の旧主屋の取り壊しから, 同年7月の地盤かさ上げまでの 3か月で行っている。そして土台下および役柱下一帯の敷石に は，三河石を特に取り寄せて用いた。

(3) 座敷および裏座敷廻りの柱に内法貫を通すことによって, 細い 柱が弱くなるのを憂い，棟梁伊藤市郎治の好みで，鉄丸ボルト

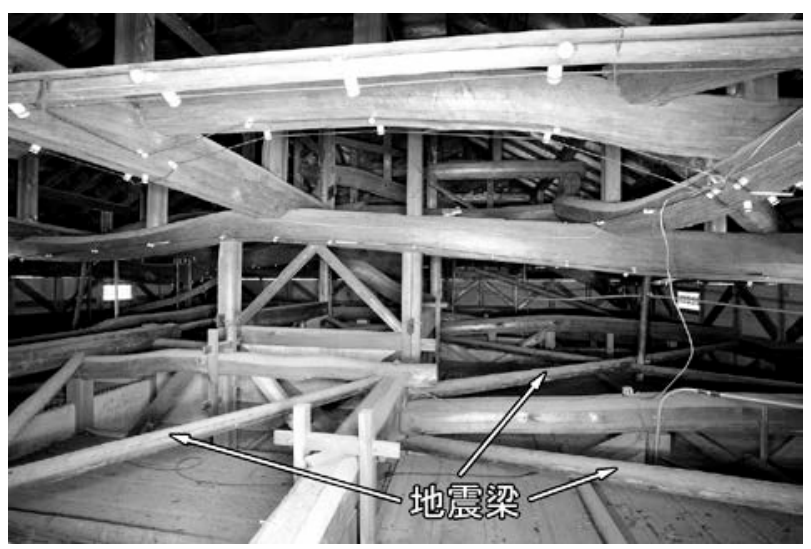

Photo4 Seismic Resistant Beam, "Jishinbari" on the Ceiling 天井上の地震梁

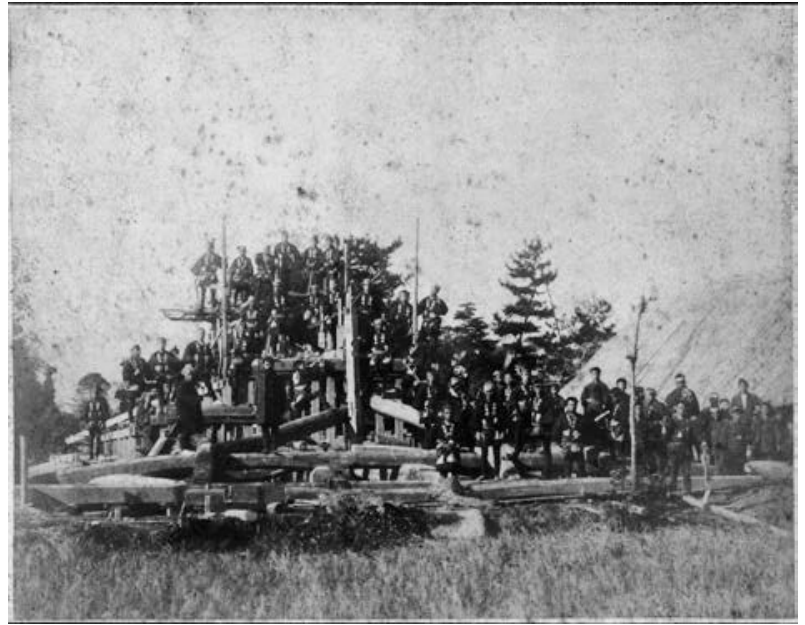

Photo5 Historical Material no. 72, 0ld Picture, Temporary assembly of the Roof Frame. Hayakawa Family Collection 史料 84 古写真 小屋組の仮組
を通して緊結するよう注意した。

(4)「地震梁」とよばれる丸太を天井上に十文字に組んだ [写真4]。 小屋組は普通とは異なるため, 一度畑で仮組を行ったうえで本 建前を行った〔写真5]。

また，史料 1 『記録帳』のほかに，史料38主屋・離れ平面図〔写 真6]にも, 主屋再建に関する注意点として, 次のとおり具体的に 記されている。

右側の記述

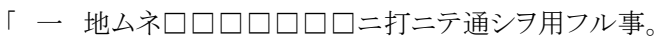

(用紙の端切断により一部判読不可能)

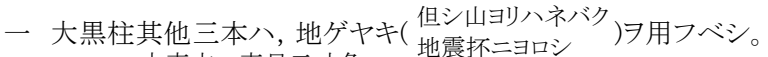
然シテ 大壱本八壱尺二寸角

一 柱八床柱ᄏ除キ, 他八五寸角以上ヨ用ュベシ。然シテ匿シ土 台ヨ用フル数個／所ニシテアリセメニシ, 土台ノ開カザル様注 意スベシ。」

下側の記述

「○地震バリ卜称スルモノアリ。必ズ用ユベシ。

技師二問合セ, 大丈夫ノスジカイフ用ユベシ。

マ 又キ其他等モ渾テコミゼンニスベシ。

○柱ノホズハ一本オキニ土臺ノ下マデ／通スハ渾テ堅固ニテヨロシ。

○ハリ等渾テ野物ハ必ス通スヨヨシトス。

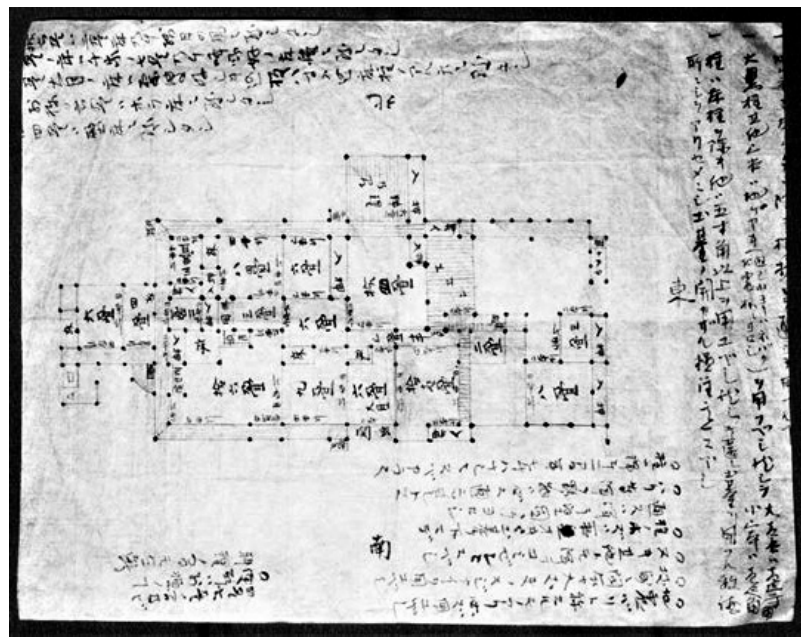

Photo6 Historical Material no. 27, The Floor Plan of the Main Building. Hayakawa Family Collection 史料 38 主屋平面図 早川家所蔵

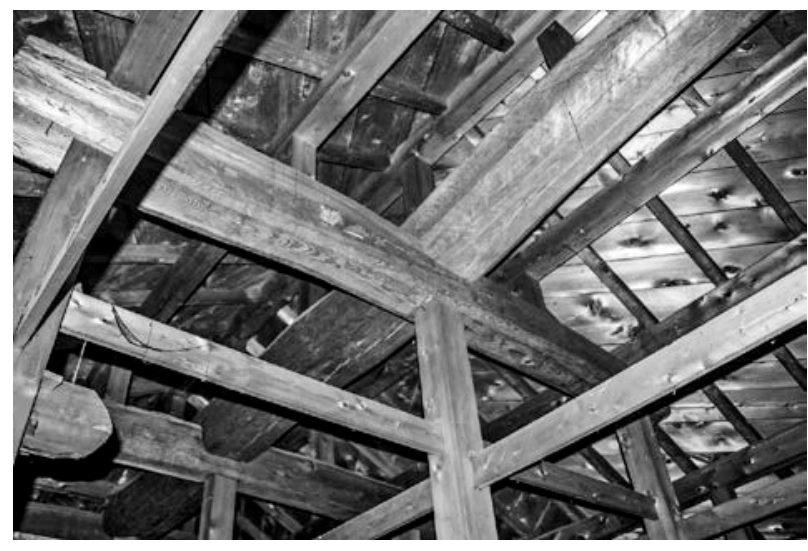

Photo7 A Roofing Board attached diagonally 斜めに張られた野地板 
柱ハ渾テ二間半モチハナシニスベカラス。

四畳六畳八間及ビ／便所八別棟ノ事。／料理ノ間モ全断。」 上側の記述

「拾六畳八二畳床, 乃チ残月の風二致シタシ。/(九)畳ノ床八千家) 七畳, 乃千啐豚好ノ床構二致シタシ。/(六)畳大目ノ床八原鼠好シ キ込板八寸入込, 床柱ノアル床二致タシ。／別棟ノ六曽八ホラ床二 致シタシ。／拾四畳八壁床二致シタシ。」

『記録帳』には記されていない耐震対策をまとめると，次のとお りとなる。

(5) 柱は床柱を除いて 5 寸角以上を用いる。

(6) 隠し土台を用いる数か所は，仕口に蟻を用い，土台が開かない ようにする。

(7) 技師に問い合わせて，十分な筋違を用いる。 なお，筋違については「木材明細書」(史料3)にも，次のとおり 記されており，筋違を使用したことは確実である。和風住宅に 使用した最初期の例として注目される。

$\begin{array}{cc}\Gamma \text { スジカイ } & \text { 同(桧) (長)武間 } \\ \text { 一拾丁 } & \text { (幅)四寸 } \\ & \text { (厚)八分 }\end{array}$

8) 貫その他は，すべて込栓止めとする。

(9) 柱の柄は，1本おきに土台まで通す。

(10)梁などの野物は，継がずに一本物を通すのがよい。

(11) 柱間は，2間半以上持ち放しにしてはいけない。

以上の他にも，耐震対策として，12)桁の隅に火打梁を入れ，(13)野 地板は斜めに張られていることが [写真 7 ] , 建物から確認できる。 これらの部材は，目視による年代判定から，周囲の当初材と同時期 であることは間違いなく，他の耐震対策と合わせて建設当初に行わ れたものである。

\section{6. 先駆的耐震建築としての特質}

幕末・明治初期以来，わが国の建築学が近代化していく中で，木 造伝統構法にも近代化としての変化・工夫が加えられた。とりわけ 濃尾地震(明治 24 年)以降の度重なる震災被害に対して, 学士建築家 を中心に耐震化が進められた結果, わが国の伝統構法の弱点の指摘 と, その欠点を解消するための改良案が考案された。すなわち, 濃 尾地震の翌明治 25 年 6 月に設置された震災予防調査会が，明治 27 年の山形県酒田地方震災の復興家屋構造の指針として「木造耐震家 屋構造要領」を発表した。さらにそれより早く明治 $25 \sim 26$ 年に，ジ ヨサイア・コンドルや伊藤為吉が『建築雑誌』に発表した論文等に おいても, 従来の日本家屋構造の欠陥として, (1)屋根重量の過大な ること, (2)柱が孤立していること, (3)柿穴等継手仕口の部材の切り 欠きが多いこと，(4)貫や楔による固定が一時的であることなどをあ げ，筋違や土台の設置の必要性，木造各部の固定金物の考案とその 使用法などを説いている5) 7)。

このような濃尾地震後の建築学界の状況において, 早川周造が濃 尾地震の直後に被害を独自で分析し, 復興に際しては, 遅くとも上 棟式が行われた明治 25 年 12 月 30 日までに, 大工棟梁や技師に相 談しながら，前節で指摘した耐震性を考慮した松杭とコンクリート を用いた地盤の構法や, 筋違, 火打梁, 「地震梁」, 野地板の斜め張 り，ボルトの使用などの木造軸組構法を採用した先駆性は，とりわ け注目に值する。

\section{7. 結}

i 早川家住宅は，濃尾地震で甚大な被害を受けたが，それを教訓 として, 地盤や構造について耐震性に新たな工夫が凝らされたこ とが，文献史料と現存建物から具体的に確認できる。而震性を考 慮した木造軸組構法の近代化の先駆的事例として注目される。

ii 豊富な文献史料により, 複数の茶匠を含めた建築関係者の全容 が，克明に確認できる。

iii 今後は, 本稿で紹介した豊富な図面史料をもとに, 平面検討の 経緯，茶匠との書簡や図面史料による室内意匠検討の経緯を考察 する予定であるが，早川家住宅は，いまだ建築家の職能が確立す る以前に，地方屈指の素封家であり，文化人かつ近代数寄者でも ある当主が，自邸建設にどのようなかかわり方をしたかを，実証 的に解明できる貴重な例といえる。

\section{謝辞}

本研究を進めるにあたり，早川家および海津市教育委員会から実 測調査および史料閲覧・撮影等にご協力を賜りました。ここに深く 謝意を表します。

\section{参考文献}

1) Kazuyoshi Fumoto, Yoshihiro Narumi, Shigeru Kubodera, and Ryogo Tachi : Report on Comprehensive research of Japanese-style modern Architecture in Gifu Prefecture, Educational Committee of Gifu Prefecture, 2016.3 (in Japanese)

麓和善・鳴海祥博・窪寺茂・舘龍午：岐阜県近代和風総合調査報告書, 岐阜県教育委員会, 2016.3

2) Masao Nakamura: Hayakawa Residence Part1, Japanese Architecture, No. 18, Kenchiku Shiryo Kenkyusha pp160-163, 1983. 12 (in Japanese) Masao Nakamura: Hayakawa Residence Part2, Japanese Architecture, No. 19, Kenchiku Shiryo Kenkyusha pp170-173, 1984.2(in Japanese) 中村昌生：早川邸之の 1 , 和風建築, 第 18 号, 建築資料研究社, pp160-163, 1983.12, 中村昌生 : 早川邸その 2, 和風建築, 第 19 号, 建 築資料研究社, pp170-173, 1984.2

3) Takahiro Shimizu, Katsuhiro Kawata: Research on Shuzo Hayakawa residence of Kaizu city, Gifu Prefecture - The transition of building within natural disaster and its countermeasures-. Japan Architecture Committee Tokai Branch research report No. 51, pp709-712，2013.2(in Japanese)

清水隆宏・河田克博：岐阜県海津市旧早川周造邸の研究一自然災害に よる邸内建築の変遷とその対策について一，日本建築学会東海支部研 究報告, 第 51 号, pp709-712, 2013.2

4) Tatsuharu Nakanishi: Lord of Parliament, Shuzo Hayakawa, an extraordinary intellectual from Seinou, Arena, No.11, Chubu University, pp. 349-356 2011.4(in Japanese)

中西達治 : 貴族院議員早川周造西濃から出た不世出の文化人，アリーナ, 第 11 号, 中部大学, pp.349-356, 2011.4

5) Josiah Conder (speechifier), Daikichi Taki (translator), Kenkichi Ichihigashi (stenographer): Effects of the recent earthquakes on various building types, Journal of Architecture and Building Science, No.63, pp63-67, 1892.3, No.64, pp92-99, 1892.4, No.65, pp132-137, 1892.5(in Japanese)

ゼー，コンドル氏演説，瀧大吉氏口訳，市東謙吉速記：各種建物 二関シ近来ノ地震ノ結果, 建築雑誌, 第 63 号, pp63-67, 1892 年 3 月,第 64 号， pp92-99，1892.4，65号， pp132-137，1892.5

6) Tamekichi Ito: Methods on the structural improvement of Japan's architecture. Kyoueki Shousha, 1891.12(in Japanese) 伊藤為吉：日本建築構造改良法，共益商社，1891. 12

7) Tamekichi Ito (speechifier), Kenkichi Ichihara (stenographer): Construction methods regarding earthquakes. Journal of Architecture and Building Science, No.73, pp12-26, 1893.1(in Japanese) 伊藤為吉演説，市東謙吉速記：地震に関する工法片々，建築雑誌， 第 73 号, 1893. 1 


\title{
A STUDY ON HISTORICAL MATERIALS OF ARCHITECTURE AND SEISMIC COUNTERMEASURES
} ADOPTED AFTER THE NOBI EARTHQUAKE OF HAYAKAWA RESIDENCE

- A study on the modern Japanese-style architecture, Hayakawa residence. Part. 1 -

\author{
Kazuyoshi FUMOTO ${ }^{* 1}$, Takako MIZUNO ${ }^{* 2}$ and Shinichi HAMADA ${ }^{* 3}$ \\ ${ }^{* 1}$ Prof., Dept. of Architecture, Graduate School of Socio Engineering, Nagoya Institute of Technology, Dr.Eng. \\ *2 Grad. Student, Graduate School of Socio Engineering, Nagoya Institute of Technology \\ ${ }^{* 3}$ The Japanese Association for Conservation of Architectural Monuments, Dr.Eng.
}

Hayakawa residence is a rural mansion, which is a preeminent modern Japanese-style house in Gifu prefecture. Most heads of rural mansions had interaction with entrepreneur and major merchants. They were highly sophisticated, intellectual and also tea ceremony masters. Furthermore, before architects gained its profession, the heads of the family, which had deep insight and intuition for architecture mainly planned and designed the residences, rather than the carpenters. There are many historical materials preserved at Hayakawa residence. In detail, they describe the role of the head, when constructing residences. Also, many buildings of Hayakawa residence were severely damaged by the Nobi Earthquake that took place in 1981 and was reconstructed immediately after the Earthquake.

The following details of the seismic countermeasure taken place whilst the reconstruction can be identified: 1) The ground water level is $2.4 \mathrm{~m}$ below the current ground level. 40 holes were dug at ground water level. In each hole, 9 to 10 pine pillars were placed for the foundation. The pillars' diameter is $15 \mathrm{~cm}$ and is about $3 \mathrm{~m}$ long. 2) Concerned of the thin pillars at the formal Japanese room weakened by the penetrating tie beam, the master carpenter's suggested binding the pillars and the penetrating tie beam with round iron bolts.

3) A round timber called "Jishinbari" was put together in a cross above the ceiling as a brace.

4) Besides "Tokobashira" pillars' sizes are all over $15 \mathrm{~cm}$ squared.

5) A specific joint is used at the foundation, where it cannot be seen from the outside, to prevent it from sliding.

6) The main Carpenter gave and advice on whether the number of braces is enough or not.

7) Penetrating tie beams are all plugged to the pillars.

8) The pivot used at pillars alternatively reaches to the base.

9) The beams were not patched, using one timber.

10) In addition to the seismic countermeasures that can be verified by the historical materials, which are listed above, it can be seen in the remaining buildings that an angle beam is inserted at the corner of the girder and the roof boards are attached diagonally.

Since Last of Edo and Meiji Era, along with the modernization of architecture in our country, traditional timber construction has also changed and innovated in modernization.

Especially from the repeated seismic disaster after the Nobi Earthquake in 1891, seismic countermeasures have evolved through architects with the degree. They pointed out the weakness of the traditional construction and devised a resolution plan. As one of the first examples, "A Document on seismic countermeasure of timber structure residences" was published by the Investigation Committee for earthquake disaster prevention, which was established in June 1892, after a year from Nobi Earthquake, to use it as a guideline at Yamagata Prefecture, Sakata area's reconstruction residence's structure. In addition, Tamekichi Ito insisted the necessity of braces and foundation, as well as devising fixed hardware and showed an example of how to use them in the thesis he publicized at "Journal of Architecture and Building Science". He devised that there are four defects in the traditional wooden frame construction:

1.The weight of the roof is too heavy. 2. The pillars are isolated. 3. The structures are being cut for joints and elongating. 4 . The binding done by penetrating tie beam and wedges are only temporary.

Under these circumstances after Nobi Earthquake, Shuzo Hayakawa analyzed the seismic damage by himself, and when at reconstruction, he introduced construction method of foundation and wooden frame structure as a countermeasure for the earthquake. His pioneering acts are admirable. 